\title{
Molecular detection of exfoliative toxin in Staphylococcus intermedius isolates from dogs with pyoderma"
}

\author{
Barış SAREYYÜPOĞLU ${ }^{1}$, H. Kaan MÜŞTAK ${ }^{1}$, Zafer CANTEKİN $^{2}$, K. Serdar DİKER $^{1}$ \\ ${ }^{1}$ Department of Microbiology, Faculty of Veterinary Medicine, Ankara University, 06110, Diskapi, Ankara; ${ }^{2}$ Department of \\ Microbiology, Faculty of Veterinary Medicine, Mustafa Kemal University, Serinyol, Antakya, Turkey.
}

Summary: Staphylococcus aureus and S. intermedius are considered as the most significant species causing skin infections in dogs. The aim of this study was to develop a Polymerase Chain Reaction technique for the detection of siet $(S$. intermedius exfoliative toxin) gene encoding exfoliative toxin in $S$. intermedius and to investigate its presence in $S$. intermedius isolates from dogs with pyoderma. A total of 41 isolates (35 S. intermedius, 4 S. aureus, one $S$. capitis subsp. ureolytica and one $S$. chromogenes) from dogs with pyoderma were included in the study. Original primers specifically amplifying $145 \mathrm{bp}$ of siet gene and $182 \mathrm{bp}$ of agr (accessory gene regulator) gene locus of $S$. intermedius were designed in the study. agr gene was detected in all $S$. intermedius isolates, but not in other isolates. siet gene was detected in all S. intermedius isolates. siet Polymerase Chain Reaction assay was found to be specific since no amplifications were observed with siet negative $S$. intermedius and other bacterial control strains. Rapid and reliable detection of staphylococci causing skin lesions in dogs and their virulence markers like siet gene will provide important data for clinical practice to manage the disease more effectively by means of treatment and prevention.

Key words: Canine pyoderma, exfoliative toxin, siet gene, Staphylococcus intermedius.

\section{Piyodermalı köpeklerden izole edilen Staphylococcus intermedius'larda eksfoliatif toksin varlığının moleküler olarak belirlenmesi}

Özet: Staphylococcus aureus ve S. intermedius'un köpeklerde deri enfeksiyonlarına neden olan en önemli türler olduğu kabul edilmektedir. Bu çalışmada, S. intermedius'un eksfoliatif toksinini kodlayan siet (S. intermedius eksfoliatif toksin) genini belirlemek için bir Polimeraz Zincir Reaksiyonu (PCR) tekniği geliştirilmesi ve piyodermalı köpeklerden izole edilen $S$. intermedius izolatlarında bu genin araştırılması amaçlandı. Piyodermalı köpeklerden izole edilen toplam 41 izolat (35 S. intermedius, 4 S. aureus, bir $S$. capitis subsp. ureolytica ve bir $S$. chromogenes) çalışmaya dahil edildi. Bu çalışmada, siet geninin 145 bp'lik ve $S$. intermedius'un agr (accessory gene regulator) geninin 182 bp'lik bölümünü spesifik olarak çoğaltan özgün primerler tasarlandı. agr geni diğer stafilokok türlerinde değil sadece $S$. intermedius izolatlarında tespit edildi. Bütün $S$. intermedius'larda siet geni saptandı. Diğer kontrol suşlarında ve siet negatif $S$. intermedius suşunda amplifikasyon görülmediği için siet PCR yöntemi spesifik bulundu. Köpeklerde deri lezyonu oluşturan stafilokokların ve bu stafilokokların virulens özelliklerinden siet geninin hızlı ve güvenilir olarak belirlenmesi, tedavi ve korunma anlamında hastalıkla daha etkili mücadele için klinik olarak önemli bilgiler sunacaktır.

Anahtar sözcükler: Eksfoliatif toksin, köpek, piyoderma, siet geni, Staphylococcus intermedius

\section{Introduction}

Staphylococci are commonly isolated in routine veterinary diagnostics. Among the various coagulasepositive staphylococci which could be recovered from diseased and healthy dogs, Staphylococcus intermedius and $S$. aureus have been considered as the most significant species $(8,14)$. $S$. intermedius, first described by Hajek (12), is the most common cause of skin infections in dogs, with canine pyoderma being caused almost exclusively by $S$. intermedius $(16,37)$. It has also been isolated from a number of other carnivores, horses, ruminants and birds $(7,13,18,22,23)$. In single cases, $S$. intermedius appears to be also responsible, as a zoonotic pathogen, for canine-inflicted human wound infections and invasive infections in immune compromised patients $(28,31)$.

Similar to $S$. aureus, $S$. intermedius produces many virulence factors such as protease, coagulase, clumping factor, enterotoxins, exfoliative toxin, leukotoxin, and hemolysins $(10,11,12,22,29)$. It has been reported that the enterotoxin- and/or leukotoxin-producing $S$. intermedius strains are prevalent in dogs $(10,11)$. Terauchi et al. (29) revealed that $S$. intermedius D-52 isolated from canine pyoderma produced an exfoliative toxin (SIET). The

* This study was derived from the $\mathrm{PhD}$ thesis of the second author. 
molecular mass of SIET has been estimated to be 30 $\mathrm{kDa}$, as determined by sodium dodecyl sulfatepolyacrylamide gel electrophoresis (SDS-PAGE); this toxin differs from $S$. aureus exfoliative toxins (i.e. ETA, ETB, and ETC) and Staphylococcus hyicus exfoliative toxins (SHETA and SHETB) in molecular weight and antigenicity. Furthermore, SIET causes exfoliation in 1day-old chickens, suckling hamsters, and 3-week-old dogs, in contrast to the respective effects of ETs and SHETs (29). The siet gene, located on the chromosomal DNA, consists of a coding region of $990 \mathrm{bp}$ specifying a polypeptide of 330 amino acid residues (30). Until recently, bioassays have been used to detect SIET, while molecular approaches have been searched to detect genes encoding exfoliative toxins (6). A Polymerase Chain Reaction (PCR) assay, for amplification of siet gene, has been developed by Lautz et al. (19).

In this study a PCR technique for the detection of siet gene encoding exfoliative toxin in S. intermedius was developed and used for the investigation of the presence of this gene in $S$. intermedius isolates from dogs with pyoderma.

\section{Materials and Methods}

Bacterial strains: A total of 41 Staphylococcus isolates (35 S. intermedius, $4 S$. aureus, one S. capitis subsp. ureolytica and one $S$. chromogenes) from dogs with pyoderma, obtained in years 2005-2006 were used in this study. siet positive and negative $S$. intermedius strains, and an ETA/ETB positive $S$. aureus strain were kindly provided by Prof. Christoph Laemmler (Institut fur Pharmokologie und Toxikologie, Justug-LiebigUniversitat Giessen, Germany). A S. intermedius strain was also provided by Dr. Karsten Becker, (Institut für Medizinische Mikrobiologie, Universität Münster). Bacterial strains from culture collection of Department of Microbiology (Faculty of Veterinary Medicine, Ankara University, Ankara, Turkey) used as negative control in specificity tests for PCR analysis were Escherichia coli AVMC96-134, Pseudomonas aeruginosa AVMC95-61, Pasteurella multocida AVMC88-33, Klebsiella pneumoniae AVMC87-28, Serratia marcescens AVMC95-17, Enterococcus faecalis AVMC99-87, S. aureus AVMC96-
122, S. intermedius AVMC97-132, S. hyicus AVMC97117, S. chromogenes AVMC97-119, and S. schleiferi AVMC99-28. In addition, staphylococcal strains like $S$. aureus RSKK95-044, S. chromogenes RSKK95-051, S. hyicus RSKK95-050, S. hominis RSKK95-050 from national type culture collection (Refik Saydam Hıfzısıhha Merkezi, Ankara, Turkey) were also included in the study. All bacterial strains were stored at $-70^{\circ} \mathrm{C}$ until used.

Phenotypic characteristics of Staphylococcal isolates: Isolates were cultured on Columbia agar with 5\% (vol/vol) sheep blood and incubated at $37^{\circ} \mathrm{C}$ for $24 \mathrm{~h}$. Suspected colonies were Gram stained and investigated by conventional biochemical tests and Microbact Staph 12S Identification System (Oxoid, MB1561).

Preparation of DNA samples: A modified phenolchloroform extraction method was performed for DNA extraction (4). Briefly, $1 \mathrm{ml}$ of bacterial culture that had been replicating overnight in Brain Heart Infusion Broth (Oxoid, CM1135) was centrifuged for $4 \mathrm{~min}$ at $2500 \times \mathrm{g}$ in sterile microcentrifuge tubes. After washing once in TE buffer (10 mM Tris, 1mM EDTA, pH 7.8), the pellet was incubated for $1 \mathrm{~h}$ at $37^{\circ} \mathrm{C}$ in $400 \mu \mathrm{l}$ of TE buffer containing lysostaphin on a specimen basis. At the end of that period, $375 \mu \mathrm{l}$ of STE buffer $(10 \mathrm{mM}$ Tris- $\mathrm{HCl}, \mathrm{pH}$ $8.0,100 \mathrm{mM} \mathrm{NaCl}, 25 \mathrm{mM}$ EDTA), $20 \mu \mathrm{l}$ of sodium dodecyl sulfate (SDS) and $5 \mu 1$ of $10 \%$ proteinase K (20 $\mathrm{mg} / \mathrm{ml}$ ) were added to the mixture and incubated for $1 \mathrm{~h}$ at $56^{\circ} \mathrm{C}$. Phenol-chloroform extraction was then performed as described by Sambrook et al. (24). Isolated DNA was kept at $-20^{\circ} \mathrm{C}$ until use.

Primers used in the study: The siet (Genbank no: $\mathrm{AB} 099710)$ and $a g r$ (accessory gene regulator) gene locus (Genbank no: AY557375) sequence data were obtained from GenBank and used for designing the oligonucleotide primers specific to siet and $S$. intermedius. Primers specifically amplifying a $684 \mathrm{bp}$ portion of femA gene of S. aureus (32) and $420 \mathrm{bp}$ of $16 \mathrm{~S}$ rDNA of staphylococci (27) were used for molecular confirmation of $S$. aureus strains or whether the bacterial strain belongs to Staphylococcus genus or not, respectively. All oligonucleotide primers were synthesized by Operon (Cologne, Germany) (Table 1).

Table 1. Oligonucleotide primers used in this study.

Tablo 1. Çalışmada kullanılan oligonukleotid primerler.

\begin{tabular}{|c|c|c|c|c|}
\hline Gene & Primer & Oligonucleotide sequence (5'-3') & PCR products & Reference \\
\hline \multirow{2}{*}{ femA } & Fem1 & CTTACTTACTGCTGTACCTG & \multirow{2}{*}{$684 \mathrm{bp}$} & \multirow{2}{*}{ Vannufel et al. (1995) } \\
\hline & Fem2 & ATCTCGCTTGTTATGTGC & & \\
\hline \multirow{2}{*}{$a g r$} & Sint1 & AAATCCCTGCTGAGTTGTTAGAAG & \multirow{2}{*}{$182 \mathrm{bp}$} & \multirow{2}{*}{ This study } \\
\hline & Sint2 & ACTATCCCGAAGATGAGAAGAATG & & \\
\hline \multirow{2}{*}{ siet } & Siet1 & AGCGTTAATAGTCCGGGTGG & \multirow{2}{*}{$145 \mathrm{bp}$} & \multirow{2}{*}{ This study } \\
\hline & Siet2 & CGGCTGGTGCTGAAATGTAG & & \\
\hline \multirow{2}{*}{ 16S rDNA } & $16 s 1$ & CAG CTC GTG TCG TGA GAT GT & \multirow{2}{*}{$420 \mathrm{bp}$} & \multirow{2}{*}{ Strommenger et al. (2003) } \\
\hline & $16 \mathrm{~s} 2$ & AAT CAT TTG TCC CAC CTT CG & & \\
\hline
\end{tabular}


PCR and sequencing of siet gene: The reaction mixture of siet amplification contained $1 \mu \mathrm{l}$ of each primer $(10 \mathrm{pmol} / \mu \mathrm{l}), 0.5 \mu \mathrm{l}$ of dNTP $(10 \mathrm{mM}$, Fermentas, Vilnius, Lithuania), $2.5 \mu$ of $10 \times$ Taq DNA polymerase buffer (Fermentas, Vilnius, Lithuania) with a final concentration of $2 \mathrm{mM} \mathrm{MgCl} 2,0.2 \mu \mathrm{l}$ of Taq DNA polymerase ( $5 \mathrm{U} / \mu 1$, Fermentas, Vilnius, Lithuania) and $15.8 \mu 1$ of sterile DEPC treated water (Fermentas, Vilnius, Lithuania). Amplification conditions for siet and agr genes were: initial denaturation at $94^{\circ} \mathrm{C}$ for $3 \mathrm{~min} ; 30$ cycles of $94^{\circ} \mathrm{C}$ for $30 \mathrm{~s}, 54^{\circ} \mathrm{C}$ for $30 \mathrm{~s}, 72^{\circ} \mathrm{C}$ for $30 \mathrm{~s}$; and final extension at $72^{\circ} \mathrm{C}$ for $3 \mathrm{~min}$. Beside this amplification conditions were: initial denaturation at $94^{\circ} \mathrm{C}$ for $3 \mathrm{~min} ; 30$ cycles of $94^{\circ} \mathrm{C}$ for $1 \mathrm{~min}, 52^{\circ} \mathrm{C}$ for 1 $\min , 72^{\circ} \mathrm{C}$ for $1 \mathrm{~min}$; and final extension at $72^{\circ} \mathrm{C}$ for 7 min assigned for femA (32) and 16S rDNA genes (27).

PCR cleansing and sequencing of the siet amplicon of a single $S$. intermedius strain was performed by REFGEN (METU Teknokent, Ankara, Turkey). The partial sequence of the strain has been submitted to the GenBank database and accession number assigned as EU090231. A sequence comparison was carried out by using the database of the National Center for Biotechnology Information available under http://www.ncbi.nlm.nih.gov/BLAST.

\section{Results}

Molecular confirmation of isolates: Following PCR tests all isolates had $420 \mathrm{bp}$ long specific sequence of $16 \mathrm{~S}$ rDNA gene conforming that they all belong to Staphylococcus genus. agr and femA genes were respectively found in $S$. intermedius and $S$. aureus isolates, but not detected in other isolates. It was observed that isolate 17 which was determined as $S$. aureus phenotypically had both agr and femA genes.

PCR detection of siet gene: siet gene was detected in all $(100 \%)$ of the $S$. intermedius isolates and isolate 17 designated as $S$. aureus; $S$. chromogenes and $S$. capitis subsp. ureolytica isolates and all $3 \mathrm{~S}$. aureus isolates were siet negative. No amplification was observed with siet specific primers in PCR tests with DNAs obtained from E. coli, $P$. aeruginosa, $P$. multocida, $K$. pneumoniae, S. marcescens, E. faecalis, S. aureus, $S$. intermedius, S. hyicus, S. chromogenes, and S.schleiferi.

Sequencing of partial sequence of siet gene: Following sequencing of the siet amplicon of a single $S$. intermedius isolate, a partial sequence of siet gene of 145 bp long was obtained (Genbank no: EU090231). This sequence gave a $100 \%$ sequence similarity with the siet gene sequence in BLAST search. This sequence was translated into amino acid sequence and compared to the amino acid sequence of SIET. The amino acid sequence of the S. intermedius isolated was found to be $100 \%$ identical to that of SIET sequence.

\section{Discussion and Conclusion}

We aimed to develop a PCR technique for the detection of siet gene encoding exfoliative toxin in $S$. intermedius and used it for the investigation of the presence of this gene in $S$. intermedius isolates from dogs with pyoderma in this study.

Staphylococcal pyoderma is the most common skin disease in dogs. Canine pyoderma is caused almost exclusively by $S$. intermedius $(12,20)$. However, the increasing prevalence of $S$. aureus infections and the emergence of a new species like $S$. schleiferi force the veterinary community to become more vigilant to prevent zoonosis $(33,35)$. Other Staphylococcus species isolated from canine pyodermas and dermatitis were $S$. hyicus, S. epidermidis, S. xylosus, S. simulans, S. hominis $(20,21)$, and S. chromogenes, S. sciuri, S. saprophyticus, $S$. capitis (15), respectively. S. intermedius (85.4\%) and $S$. aureus $(9.8 \%)$ isolates from the dogs with pyoderma constituted the main material of this study.

Exfoliative toxins or epidermolysins are exotoxins produced by staphylococci causing skin lesions in humans and animals. ETA, ETB or both produced by $S$. aureus strains cause the staphylococcal scaled skin syndrome, characterized by the splitting of the epidermis and exfoliation (21). It was also shown that $S$. aureus produces a third exfoliative toxin ETC, which was isolated from a strain obtained from a horse phlegmon (25). Virulent $S$. hyicus, as causative agent of exudative epidermitis in pigs, produce exfoliative toxins, which differ in their amino acid sequence and were designated as SHETA and SHETB in Japan (26) and as ExhA, ExhB, ExhC and ExhD in Denmark (1). More recently, a fourth exfoliative toxin from $S$. aureus, designated ETD, and the exfoliative toxin SIET from $S$. intermedius were described by Yamaguchi et al. (34) and Terauchi et al. (29), respectively. Since $S$. intermedius has no toxin types like other skin-pathogenic staphylococci, we targeted the siet gene in particular.

In the present study, we developed a PCR assay using newly designed primers which specifically amplifies a $145 \mathrm{bp}$ sequence of the siet gene encoding exfoliative toxin of $S$. intermedius isolates. In recent years, with its increasing advantages, PCR has been used widely in the field of both medical sciences and veterinary medicine for molecular identification of infectious agents and detection of their virulence markers. There are previous studies on investigation of exfoliative toxin genes by molecular methods such as PCR $(17,19)$ and multiplex PCR $(2,3)$. Lautz et al. (19) developed a PCR technique which specifically amplifies a $359 \mathrm{bp}$ portion of the siet gene. They detected that only $62 \%$ of the $S$. intermedius from skin and wound infections were siet positive. Using this PCR assay we found that all $S$. intermedius isolates from dogs with pyoderma harbored the siet gene. Additionally, siet PCR 
performed in our study was $100 \%$ specific since no amplifications were observed with negative control $S$. intermedius strains and other bacteria examined. Furthermore, we also confirmed our results with PCR assays performed with the primers designed by Lautz et al. (19). SIET, the exfoliative toxin from $S$. intermedius was described by Yamaguchi et al. (34), and Terauchi et al. (29). The nucleotide sequence of the SIET encoding gene consists of a coding region of $990 \mathrm{bp}$ (30). Our partial sequence showed $100 \%$ homology with this gene.

In this study, we designed primers those specifically amplify the agr gene of $S$. intermedius and used them for molecular confirmation of $S$. intermedius isolates. These primers have specifically discriminated $S$. intermedius strains from other staphylococci. Furthermore, we tested our isolates by singleplex PCR tests with primers amplifying femA for molecular confirmation of $S$. aureus isolates, and also with primers amplifying a specific sequence of $16 \mathrm{~S}$ rDNA gene in order to confirm the isolates whether they belong to Staphylococcus genus. Baron et al. (5) developed a multiplex PCR that could differentiate between $S$. aureus and $S$. intermedius that targets species-specific sequences in the nuc gene, which encodes thermonuclease in the two species. Lautz et al. (19) used this technique to discriminate their isolates. In a previous study of Ardic et al. (4), a multiplex PCR technique co-amplifying $16 \mathrm{~S}$ rDNA portion of staphylococci and femA gene of $S$. aureus was developed. Interestingly, we detected both femA gene specific for $S$. aureus and agr gene specific for $S$. intermedius in one isolate, isolate 17. Although this isolate was identified as S. aureus with Microbact Staph 12S System, we believe the culture of the isolate could be contaminated with the cells of the related bacteria originated from the swab sample, or there could be a cross-contamination of DNA in either of the relevant PCR tests.

We believe that it could be a valuable approach to design specific primers which could be used to develop multiplex PCR techniques for the molecular detection and discrimination of important pathogens isolated from pet and companion animals. Recent studies showed that staphylococcal isolates from skin infections of dogs phenotypically identified as $S$. intermedius could indeed be Staphylococcus pseudintermedius (9, 36, 37). According to this new finding further investigations have to be done for the discrimination and confirmation of the two species. Molecular discrimination of $S$. intermedius, S. pseudintermedius, and S. delphini isolated from canine pyoderma with multiplex PCR could be a good start point.

As a conclusion, rapid and reliable detection of staphylococci causing skin lesions in dogs and their virulence markers like siet gene will provide important data for clinical practice to manage the disease more effectively by means of treatment and prevention.

\section{Acknowledgements}

We thank Prof. C. Lämmler, Justus-Liebig-Universität Gießen and Dr. K. Becker, Universität Münster for providing us siet-PCR positive, siet-PCR negative and $S$. intermedius and $S$. aureus strains to be used as control strains in the study.

\section{References}

1. Ahrens P, Andresen LO (2004): Cloning and sequence analysis of genes encoding Staphylococcus hyicus exfoliative toxin types $A, B, C$, and D. J Bacteriol, 186, 1833-37.

2. Andresen LO (2005): Production of exfoliative toxin by isolates of Staphylococcus hyicus from different countries. Vet Rec, 157, 376-378.

3. Andresen LO, Ahrens P, Daugaard L, Bille-Hansen V (2005): Exudative epidermitis in pigs caused by toxigenic Staphylococcus chromogenes. Vet Rec, 105, 291-300.

4. Ardic N, Ozyurt M, Sareyyupoglu B, Haznedaroglu T (2005): Investigation of erythromycin and tetracycline resistance genes in methicillin-resistant staphylococci. Int J Antimicrob Agents, 26, 213-218.

5. Baron F, Cochet M, Pellerini JL, Zakour NB, Lebon A, Navarro A, Proudy I, Le Loir Y, Gaultier M (2004): Development of a PCR test to differentiate between Staphylococcus aureus and Staphylococcus intermedius. J Food Prot, 67, 2302-05.

6. Becker K, Roth R, Peters G (1998): Rapid and specific detection of toxigenic Staphylococcus aureus: use of two multiplex PCR enzyme immunoassays for amplification and hybridization of staphylococcal enterotoxin genes, exfoliative toxin genes, and toxic shock syndrome toxin 1 gene. J Clin Microbiol, 36, 2548-53.

7. Bes M, Slim LS, Becharnia F, Meugnier H, Vandenesch F, Etienne J, Freney J (2002): Population diversity of Staphylococcus intermedius isolates from various host species: typing by $16 \mathrm{~S}-23 \mathrm{~S}$ intergenic ribosomal DNA spacer polymorphism analysis. J Clin Microbiol, 40, 227577.

8. Biberstein EL, Jang SS, Hirsh DC (1984): Species distribution of coagulase-positive staphylococci in animals. J Clin Microbiol, 19, 610-615.

9. Devriese LA, Vancanneyt M, Baele M, Vaneechoutte M, De Graef E, Snauwaert C, Cleenwerck I, Dawyndt P, Swings J, Decostere A, Haesebrouck F (2005): Staphylococcus pseudintermedius sp. nov., a coagulasepositive species from animals. Int J Syst Evol Microbiol, 55, 1569-73.

10. Futagawa-Saito K, Sugiyama T, Karube S, Sakurai N, Ba-Thein W, Fukuyasu T (2004a): Prevalence and characterization of leukotoxin-producing Staphylococcus intermedius isolates from dogs and pigeons. J ClinMicrobiol, 42, 5324-26.

11. Futagawa-Saito K, Suzuki M, Ohsawa M, Ohshima S, Sakurai N, Ba-Thein W, Fukuyasu T (2004b): Identification and prevalence of an enterotoxin-related gene, se-int, in Staphylococcus intermedius isolates from dogs and pigeons. J Appl Microbiol, 96, 1361-66. 
12. Hajek V (1976): Staphylococcus intermedius, a new species isolated from animals. Int J Syst Bacteriol, 26, 401-408.

13. Hajek V, Balusek J, Horak V, Koukalova D (1991): Characterization of coagulase-positive staphylococci isolated from free living birds. J Hyg Epidemiol Microbiol Immunol, 35, 407-418.

14. Hartmann FA, White DG, West SEH, Walker RD, De Boer DJ (2005): Molecular characterization of Staphylococcus intermedius carriage by healthy dogs and comparison of antimicrobial susceptibility patterns to isolates from dogs with pyoderma. Vet Microbiol, 108, 119-131.

15. Hauschild T, Wojcik A (2007): Species distribution and properties of staphylococci from canine dermatitis. Res Vet Sci, 82, 1-6.

16. Ihrke PJ (1987): An overview of bacterial skin disease in the dog. Br Vet J, 143, 112-118.

17. Kanbar T, Voytenko AV, Alber J, Lammler C, Weiss R, Zschöck M, Shilov IA, Dmitrenko OA, Gintsburg AL (2006): Prevalence of genes encoding exfoliative toxins among Staphylococcus hyicus isolated in Russia and Germany. J Vet Med B Infect Dis Vet Public Health, 53, 429-433.

18. Kloos WE (1980): Natural population of the genus Staphylococcus. Annu Rev Microbiol, 34, 559-592.

19. Lautz S, Kanbar T, Alber J, Lammler C, Weiss R, Prenger-Berninghoff E, Zschöck M (2006): Dissemination of the gene encoding exfoliative toxin of Staphylococcus intermedius among strains isolated from dogs during routine microbiological diagnostics. J Vet Med B Infect Dis Vet Public Health, 53, 434-438.

20. Medleau L, Long RE, Brown J, Miller WH (1986): Frequency and antimicrobial susceptibility of Staphylococcus species isolated from canine pyodermas. Am J Vet Res, 47, 229-231.

21. Prevost G, Couppie P, Monteil H (2003): Staphylococcal epidermolysins. Curr Opin Infect Dis, 16, 71-76.

22. Raus J, Love DN (1983): Characterization of coagulasepositive Staphylococcus intermedius and Staphylococcus aureus isolated from veterinary clinical specimens. J Clin Microbiol, 18, 789-792.

23. Robertson J, Fox L, Hancock D, Gay J, Besser $\mathbf{T}$ (1996): Prevalence of coagulase-positive staphylococci, other than Staphylococcus aureus, in bovine mastitis. Am J Vet Res, 57, 54-58.

24. Sambrook J, Fritsch EF, Maniatis T (1989): Molecular Cloning: A Laboratory Manual, 2nd ed. Cold Spring Harbor Press, New York.

25. Sato H, Matsumori Y, Tanabe T, Saito H, Shimizu A, Kawano J (1994): A new type of staphylococcal exfoliative toxin from a Staphylococcus aureus strain isolated from a horse with plegmon. Infect Immun, 62, 3780-85.

26. Sato H, Watanabe K, Higuchi K, Teruya K, Ohtake A, Murata Y, Saito H, Aizawa C, Danbara H, Maehara N (2000): Chromosomal and extrachromosomal synthesis of exfoliative toxin from Staphylococcus hyicus. J Bacteriol, 182, 4069-4100.
27. Strommenger B, Kettlitz C, Werner G, Witte W (2003): Multiplex PCR assay for simultaneous detection of nine clinically relevant antibiotic resistance genes in Staphylococcus aureus. J Clin Microbiol, 41, 4089-94.

28. Talan DA, Staatz D, Staatz A, Goldstein E, Singer K, Overturf G (1989): Stapyhlococcus intermedius in canine gingiva and canine-inflicted wound infections: a newly recognized zoonotic pathogen. J Clin Microbiol, 27, 78-81.

29. Terauchi R, Sato H, Hasegawa T, Yamaguchi T, Aizawa C, Maehara N (2003a): Isolation of exfoliative toxin from Staphylococcus intermedius and its local toxicity in dogs. J Vet Microbiol, 94: 19-29.

30. Terauchi R, Sato H, Endo Y, Aizawa C, Maehara N (2003b): Cloning of the gene coding for Staphylococcus intermedius exfoliative toxin and its expression in Escherichia coli. Vet Microbiol, 94, 31-38.

31. Vandenesch F, Celard M, Arpin D, Bes M, Greenland T, Etienne J (1995): Catheter-related bacteremia associated with coagulase-positive Staphylococcus intermedius. J Clin Microbiol, 33, 2508-10.

32. Vannuffel P, Gigi J, Ezzedine H, Vandercam B, Delmee M, Wauters G, Gala JL (1995): Specific detection of methicillin-resistant Staphylococcus species by multiplex PCR. J Clin Microbiol, 33, 2864-67.

33. White SD, Brown AE, Chapman PL, Jang SS, Ihrke PJ (2005): Evaluation of aerobic bacteriologic culture of epidermal collarette specimens in dogs with superficial pyoderma. J Am Vet Med Assoc, 226, 904-908.

34. Yamaguchi T, Nishifuji K, Sasaki M, Fudaba Y, Aepfelbacher M, Takata T, Ohara M, Komatsuzawa H, Amagai M, Sugai M (2002): Identification of the Staphylococcus aureus ETD pathogenicity island which encodes a novel exfoliative toxin, ETD, and EDIN-B. Infect Immun, 70, 5835-45.

35. Yamashita K, Shimizu S, Kawano J, Uchida E, Haruna A, Igimi S (2005): Isolation and characterization of Staphylococci from external auditory meatus of dogs with or without otitis externa with special reference to Staphylococcus schleiferi subsp. coagulans isolates. J Vet Med Sci, 67, 263-268.

36. Yoo JH, Yoon JW, Lee SY, Park HM (2010): High prevalence of fluoroquinolone- and methicillin-resistant Staphylococcus pseudintermedius isolates from canine pyoderma and otitis externa in veterinary teaching hospital. J Microbiol Biotechnol, 20, 798-802.

37. Youn J, Yoon JW, Koo HC, Lim S, Park YH (2011): Prevalence and antimicrogram of Staphylococcus intermedius group isolates from veterinary staff, companion animals, and the environment veterinary hospitals in Korea. J Vet Diagn Invest, 23, 268-274.

Geliş tarihi: 24.04.2012 / Kabul tarihi: 17.07.2012
Address for correspondence:
Barış Sareyyüpoğlu
Department of Microbiology,
Faculty of Veterinary Medicine, Ankara University, 06110, Diskapi, Ankara, Turkey.
e-mail: sareyyupoglu@yahoo.com 